\title{
Menyelesaikan Konflik Kerukuan Umat Beragama Dengan Hati
}

\author{
Mashudi \\ Universitas Islam Negeri Walisongo Semarang
}

\begin{abstract}
Abstrct: This paper tries to uncover the alleged conflict regarding the building of the church in the village of the Dermolo Kembang District Jepara Regency precarious and prone to conflict ended with shade. Also who those parties are considered to play a role in the effort to create a conducive climate. As a result, first, in order to optimize the role of religious institutions to manage the plurality of fine, completion of religious harmony in the village Dermolo Jepara regency using hearted approach, meaning invited intensive communication and sit down with all parties on a regular basis until otherwise completed while wary lest result of the agreement provoked by the person who does not like the conditions of security and peace. Second, community, religious leaders, and religious institutions play an important role in creating such harmony.
\end{abstract}

Abstrak: Tulisan ini mencoba menguak konflik mengenai bangunan yang diduga gereja di Desa Dermolo Kecamatan Kembang Kabupaten Jepara yang semula genting dan rawan konflik berakhir dengan teduh. Juga siapakah pihak yang dianggap berperan dalam upaya menciptakan iklim kondusif tersebut. Hasilnya, pertama, dalam mengoptimalkan peran lembaga keagamaan untuk mengelola kemajemukan dengan baik, penyelesaian kerukunan umat beragama di Desa Dermolo Kabupaten Jepara menggunakan pendekatan hati, artinya diajak komunikasi intensif dan duduk bersama dengan semua pihak secara rutin hingga dinyatakan tuntas sambil mewaspadai jangan sampai hasil kesepakatan tersebut diprovokasi oleh oknum yang tidak suka dengan kondisi aman dan damai. Kedua, masyarakat, tokoh agama, dan lembaga keagamaan berperan penting dalam menciptakan karukunan tersebut.

Kata Kunci: Kerukunan umat beragama, hati, bangunan gereja. 


\section{PENDAHULUAN}

Kemajemukan merupakan suatu keniscayaan dalam kehidupan bersama. Demikian juga halnya keberadaan di Desa Dermolo Kecamatan Kembang Kabupaten Jepara, menunjukkan adanya keberagaman, baik dari segi kultur, budaya, ataupun pemahaman keagamaan. ${ }^{1}$ Keberagaman tersebut di satu sisi menjadi suatu kekuatan yang berpotensi untuk mendorong kemajuan Desanya, akan tetapi di sisi lain, keberagaman ini juga berpotensi menjadi titik kelemahan masyarakat dalam membangun kehidupannya yang lebihmaju. Kondisi faktual umat beragama saat ini di Desa Dermolo²menunjukkan bahwa dalambanyak hal, segi yang kedua ini yang menonjol, sehingga keberagamanyang ada belum bisa dioptimalkan untuk menjadi faktor pendorongkemajuan umat beragama.

Salah satu bukti nyata bahwa keberagaman umat di Desa Dermolo lebih banyak menjadi faktor penghambat kemajuan adalah bahwa padakenyataannya umat beragama di desa tersebut saat ini masih banyak dipusingkan oleh berbagaimacam kasus yang muncul di permukaan yang disebabkan oleh adanyakeberagaman, terutama keberagaman dalam pemahaman persyaratan pendirian rumah ibadat, kendatipun Peraturan Bersama Menteri sudah mengaturnya.

Jangankan perbedaan suatu umat beragama dengan umat-umat lainnya, kehidupan intern umat dalam satu agama saja di setiap tempat tak terkecuali di Dermolo Jepara masih ditemukan gesekan yang kalau tidak dimanaj dengan baik akan menjadi gumpalan konflik, meskipun hanya bersifat furu'iyyah. Memang harus dibedakan antara perbedaan yang bersifat furu'iyah ${ }^{3}$ dan yang bersifat ushuliyah. ${ }^{4}$ Dampaknya keberagaman yang muncul sebagai akibat dari perbedaanpemahaman keagamaan yang bersifat furu'iyah,seyogyanya dihormati sebagaimana yang telah dicontohkan para salafush shalihin, ${ }^{5}$ karena perbedaan

${ }^{1}$ Simak Buku Jepara Dalam Angka Tahun 2015 Kabupaten Jepara dan sumbersumber sekunder lainnya yang membicarakan tentang Jepara.

2 Wawancara dengan Tokoh Ulama dan Mantan Petinggi Desa Dermolo Kecamatan Kembang Kabupaten Jepara pada tahun 2015 pukul 15.30 di sebuah Hari Besar Umat Kristiani yakni menjelang upacara Natal di Desa Dermolo Kecamatan Kembang Kabupaten Jepara.

3 Penggunaan istilah keberagaman terhadap perbedaan pemahamankeagamaan yang bersifat furu'iyah.

${ }^{4}$ Sedangkan yang bersifat ushuliyah, lebih tepat diklaim sebagai penyimpangan.

5 Imam as-Syafi'i misalnya, beliau dengan tegas mengatakan : "ra'yuna shawab yabtamil al-khatha' wa ra'yu ghairina khatha yabtamil al-shawab" (pendapatku benar bisa jadi menyimpan suatu kekhilafan, begitu pula penadapat yang lain salah bisa jadi menyimpan suatu kebenaran). 
yang terjadi pada aspek ini merupakansesuatu yang tidak dapat dihindari dalam kehidupan komunal. Itulah sebabnya ada nomenklatur dari syari'at Nabi SAW yang disebut dengan "ijtihadatau min mayaadïnil ijtihad". ${ }^{6}$

Jenis perbedaan ini apabila diaplikasikan dengan baik dan benar merupakanrahmat dari Allah SWTT(ikhtilaf al-aimmah rahmab). Sebaliknya, apabila perbedaan tersebut tidak dikelola dengan baik dan benar hanya akan menjurus pada permusuhan (ikbtilaf al-aimmah 'adawah) tentu yang harus kita hindari. Sedangkan perbedaan dalam hal yang bersifat ushuliyah, perbedaan yang terjadi pada pokok-pokok ajaran agama yang sering dikenal dengan ma'lum min ad-din bi ad-dharurabdan ghairu mayaadiinil ijtibad, maka dikatagorikan sebagai penyimpangan yang harus segera dihentikan, seperti shalat dua bahasa atau lebih.

Pemerintah Kabupaten Jepara telah menyelesaikan bangunan yang diduga sebagai gereja yang belum berfungsi sebagaimana mestinya karena prosesnya sangat kontroversial, dan tidak terpenuhinya syarat-syarat bangunan rumah ibadat. Majelis Ulama Indonesia dan Forum Kerukunan Umat Beragama (FKUB) Kabupaten Jepara. Jika menyadari kondisi faktual umat beragama di lapangan (baca: Desa Dermolo Jepara) ini cukup beragam, maka sangat perlu dicarikan solusinya dengan penyamaan pola pikir dalam masalah keagamaan (taswiyah al-manhaj), koordinasi langkah strategis dalam masalah keagamaan (tansiq al-barakah) yang memberdayakan hati nurani.

Tulisan ini mencoba menguak dua hal, pertama, mengapa bangunan yang diduga gereja di Desa Dermolo Kecamatan Kembang Kabupaten Jepara yang semula selalu genting dan rawan konflik berakhir dengan teduh ? Kedua, siapakah pihak yang dianggap berperan dalam upaya menciptakan iklim kondusif tersebut?

\section{“GEREJA DERMOLO” DALAM LINTASAN WAKTU}

Menindaklanjuti Surat Jemaat Pepanthan Dermolo Nomor : 03/04/JPD/2012 tanggal 23 April 2012 tentang Permohonan Rekomendasi Pembangunan Gedung Gereja Pepanthan Dermolo kepada Ketua Forum Kerukunan Umat Beragama Kabupaten Jepara, maka dengan ini disampaikan hasil-hasil kajian setelah dilakukan pengumpulan informasi dan kunjungan ke lokasi :Pertama, berkas pengajuan rekomendasi Surat Ijin Mendirikan Bangunan dari Pemerintah Kabupaten Jepara yang diketahui Kepala Dinas Pekerjaan

${ }^{6}$ Simak terminologi Asy Syathibi dalam al-Munvafaqaat, Beirut : Dar al-Fikr, tt., hlm. 340; lihat pula Abdul Wahab Khalaf, Ushul Fiqh., Bairut : dar al-Qalam, tt., hlm. 82; Abu Zahrah, Ushul Fiqh, Kairo : Dar al-Mishr, tt., hlm. 94. 
Umum Kabupaten Jepara dengan Nomor 648/150 tanggal 09 Maret 2002 yang dialamatkan kepada Ketua GITJ Dermolo beralamat Desa Dermolo Rt 02/VI Kecamatan Kembang Kabupaten Jepara.Kedua, berkas pengajuan rekomendasi pendirian Gereja Injili di Tanah Jawa (GITJ) Dermolo telah dilampiri data warga kristiani yang turutserta menandatangani sebagai pengguna gereja berjumlah 106 orang dengan rincian sebagai berikut : Desa Dermolo (29 orang), Desa Balong (15 orang), Desa Cepogo (33 orang), Desa Jenggotan (2 orang), dan selebihnya Desa Bucu (27 orang).

Berkas pengajuan rekomendasi pendirian Gereja Injili di Tanah Jawa (GITJ) Dermolo telah dilampiri data dukungan warga masyarakat agar gereja dapat ditempati berjumlah 182 orang dengan rincian sebagai berikut : a) Dukungan dari warga yang beragama Islam (164 orang), dan b) dukungan dari warga yang beragama Budha (18 orang).

Hasil Kajian Forum Kerukunan Umat Beragama (FKUB) Kabupaten Jepara setelah dicocokkan dengan kondisi di lapangan : a) FKUB Kabupaten Jepara membenarkan adanya Surat Ijin Mendirikan Bangunan dari Pemerintah Kabupaten Jepara yang diketahui Kepala Dinas Pekerjaan Umum Kabupaten Jepara dengan Nomor 648/150 tanggal 09 Maret 2002 yang dialamatkan kepada Ketua GITJ Dermolo beralamat Desa Dermolo Rt 02/VI Kec. Kembang Kab. Jepara (duplikat tanpa dilegalisir); b) Jumlah 106 orang warga kristiani yang turutserta menandatangani berkas pengajuan rekomendasi pendirian Gereja Injili di Tanah Jawa (GITJ) Dermolo sebagaimana dalam lampiran terdiri dari beberapa desa di Kecamatan Kembang (tidak dalam satu kawasan), namun hasil dari lapangan tidak semua yang didata menjadi jemaat dalam GITJ Dermolo tersebut (hanya didata saja bukan jemaat); c)asil investigasi 164 warga masyarakat yang beragama Islam mendukung berdirinya GITJ, mayoritas menjawab tidak merasa mendukung bahkan sebagian di antaranya menolak karena tidak memenuhi syarat. Begitu pula 18 warga masyarakat yang beragama Budha, sebagian mengaku tidak merasa mendukung (tidak merasa tanda tangan).

Masalah yang ada di gereja Dermolo berawal dari keinginan warga pasamuwan yang ingin mendirikan gereja sendiri di desanya, karena sebelumnya dalam menjalankan ibadah bergabung di gereja "terdekat" di Desa Balong Beji, Kaligarang, Kelet, dan Kembang, yang jaraknya semua mencapai antara 5-8 km. Keinginan tersebut ternyata mengundang pro-kontra dari masyarakat meskipun di desa Dermolo telah terdapat 8 masjid, 12 musholla dan 1 vihara. Tak ada satu pun gereja meski warga Kristen telah bertempat tinggal sejak tahun 60-an. 
Sebagian masyarakat, dalam hal ini umat Islam, tetap tidak mengijinkan adanya gereja meskipun dalam hubungan sosial-ekonomi selama itu "baik-baik saja".7

Pada 9 Maret 2002, warga pasamuwan mendapat Ijin Mendirikan Bangunan (IMB) setelah sebelumnya sempat mendapat persetujuan tertulis dari warga sekitar lokasi gereja yang akan dibangun. Pada April 2002, gereja jadi dibangun di atas tanah hak milik atas nama Ketua GITJ Dermolo di RT. 02/VI dukuh Dombang, desa Dermolo.

Ketika pembangunan masih berjalan, tepatnya 15 April 2002 warga dukuh Dombang tiba-tiba menyatakan keberatan dan 19 April 2002 warga RT.02/VI menyampaikan pengaduan ke pemerintah kabupaten. Berikutnya, pada 10 Mei 2002 dan 15 Juni 2002, Forum Solidaritas Muslim Dermolo (FSMD) menyatakan sikap dan pengaduan kepada pemerintah kabupaten. FSMD sendiri lahir saat pembangunan gereja berlangsung sebagai respon terhadap pembangunan tersebut.Karena pengaduan dan pernyataaan sikap di atas, Pemerintah Kabupaten Jepara—setelah mendapat pertimbangan dari komisi E DPRD, MUI, Depag, Muspida dan FORKAB ${ }^{8}$ Jepara-melalui surat no. 452.2/2581 tanggal 17 Juni 2002 menyatakan, "bahwa pendirian gereja di Desa Dermolo Kecamatan Kembang, untuk saat ini tidak memungkinkan" dan mengharap Camat Kembang "segera mengambil langkah-langkah yang diperlukan untuk menjaga tetap terbinanya iklim sejuk serta mencegah terjadinya hal-hal yang tidak diinginkan."

Camat Kembang kemudian mengadakan rapat pembahasan tindak lanjut pembangunan gereja Dermolo di ruang kerja Camat Kembang pada 20 Juni 2002. Dalam rapat tersebut Camat Kembang selalu berkoordinasi dengan FKUB Kabupaten Jepara dan mengundang Danramil Bangsri, Kapolsek Bangsri, Petinggi Dermolo, Ketua BPD Dermolo, ketua panitia pembangunan gereja Dermolo, ketua NU ranting Dermolo, ketua Muhammadiyah desa Dermolo, dan ketua FSMD Dermolo.

Akhir dari rapat itu menghasilkan Surat Pernyataan yang ditandatangani M.Yuri (FSMD), Supardi (panitia pembangunan Gereja), Taslim (NU), dan Supriyanto (Muhammadiyah) yang menyatakan kesepakata; 1)Pembangunan gereja di desa Dermolo dihentikan dahulu sambil menunggu ijin baru yang akan dijalankan oleh panitia pembangunan gereja kepada Bupati Jepara. 2) Kami atas

\footnotetext{
${ }^{7}$ Wawancara dengan mantan Petinggi Desa Dermolo pada tanggal 23 September 2010 jam 19.30 di Jepara

${ }^{8}$ FORKAB (Forum Kerjasama antar Umat Beragama) Kabupaten Jepara adalah organisasi lokal yang dibentuk atas inisiatif Depag dan Pemerintah Kabupaten Jepara. Meskipun organisasi lokal, namun peresmiannya dilantik langsung oleh Menteri Agama RI, Prof. Dr. KH. Said Husin al-Munawar, MA. di Jepara.
} 
nama panitia pembangunan gereja menyetujui keputusan Bupati Jepara sebagaimana tersebut pada pokok surat tertanggal 17 Juni 2002 nomor: 452.2/2581 perihal pendirian gereja di desa Dermolo. 3) Menyetujui tidak ada konflik fisik antar umat, intimidasi dan sebagainya di desa Dermolo. 4) Bilamana ijin dari Bupati Jepara belum keluar dan kami panitia pembangunan gereja meneruskan pembangunan gereja, maka kami siap menerima sanksi untuk selamanya tidak diberi ijin pembangunan gereja. Dan 5) Bilamana ijin pembangunan gereja keluar dari Bupati Jepara, maka umat Islam di desa Dermolo dapat menerimanya.

Tindaklanjut surat pernyataan itu, panitia pembangunan gereja memohon rekomendasi gereja kepada Bupati melalui surat no. 03/PPG/GITJ-PD/6/02 tanggal 29 Juni 2002. Hasil jawaban yang diperoleh masih sama: Pemerintah Kabupaten Jepara berpendapat melalui surat no. 452.2/3901 tanggal 29 Agustus 2002 bahwa "pembangunan gereja di dukuh Dombang desa Dermolo kecamatan Kembang, untuk saat ini belum memungkinkan.” Kalimat selanjutnya, sebagaimana tertulis dalam surat yang sama, "Untuk keperluan aktivitas peribadatan umat Kristiani di desa Dermolo, tetap dapat dilakukan sebagaimana biasanya dengan mengambil lokasi di rumah warga yang bersangkutan atau gereja terdekat". Meskipun jelas-jelas masyarakat telah menentang pendirian gereja, surat ini ditutup dengan kalimat: "Kepada seluruh warga masyarakat desa Dermolo, diharap tetap menjaga persatuan dan kesatuan terutama Tri Kerukunan Beragama dengan mengedepankan semangat kebersamaan serta nilai-nilai kegotong-royongan."

Setelah rangkaian kebijakan tentang "pembangunan gereja", maka panitia pembangunan gereja menghentikan pembangunan sejak 2002, sementara aktivitas peribadatan dilaksanakan di rumah gubuk garasi mobil milik Pendeta Teofalus Tumijan, persis di belakang bangunan gereja. Jika aktifitas di bangunan gereja dipermasalahkan warga, maka aktivitas di rumah gubuk garasi itu tidak dipersoalkan meskipun untuk kebaktian, doa, sekolah minggu, dan bahkan perayaan natal. ${ }^{10}$

Pada suatu kesempatan, tepatnya tahun 2004, gereja yang dalam kondisi setengah jadi, karena beberapa pertimbangan ditempati untuk aktivitas perayaan natal. Selama beberapa tahun sebelumnya, perayaan natal dilaksanakan di balai

9 Wawancara dengan Camat Kembang, 23 September 2010 di Pendopo Kabupaten Jepara jam 20.15 WIB.

10 Bandingkan dengan hasil kajian dari Kholis Hauqola tentang bangunan yang diduga gereja di desa Desa Dermolo Kecamatan Kembang Kabupaten Jepara, tahun 2008 
desa. Akibat "penempatan" ini, akhirnya warga pasamuan mendapat penentangan "penempatan gereja". Penentangan berlangsung berlarut-larut melalui beberapa kesempatan dan pertemuan yang diadakan pemerintah desa Dermolo maupun kecamatan Kembang. Hingga akhirnya, sebagian umat Islam yang mengatasnamakan FSMD menyatakan penentangannya melalui surat pengaduan kepada Camat Kembang no. 02/FSMD/I/08 tanggal 26 Januari 2008, yang kemudian disikapi Camat Kembang dengan mengadakan pertemuan pada 4 Pebruari 2008 di pendopo kecamatan Kembang.

Dalam pertemuan 4 Pebruari 2008 itu, dipertemukan unsur pengurus FSMD dengan wakil umat Kristiani desa Dermolo. Ikut diundang juga Muspika kecamatan Kembang dan KUA kecamatan Kembang. Pertemuan ini menghasilkan surat pernyataan yang ditandatangani Supardi (wakil umat Kristen Dermolo) dan Joko Santoso (ketua FSMD) ${ }^{11}$ pada hari itu juga. Surat Pernyataan berupa kesepakatan bahwa : 1) Kegiatan ibadah umat Kristiani di desa Dermolo tetap dapat dilakukan seperti biasa yaitu di rumah Bapak Pitoyo RT.01 RW. I desa Dermolo; 2) Sedangkan untuk rumah tinggal bapak Supardi di RT. 02 RW. VI untuk sementara tidak digunakan sebagai tempat ibadah umat Kristiani, sebelum mendapatkan ijin sementara dari Bupati Jepara; 3) Apabila masingmasing pihak tersebut di atas mengingkari pernyataan ini maka siap untuk dituntut sesuai hukum/peraturan yang berlaku.

Rumah tinggal Bapak Supardi sebagaimana pada poin 2 pernyataan kesepakatan di atas adalah bangunan gereja yang dipermasalahkan. Penyebutan itu muncul karena adanya selisih pemahaman antara FSMD dengan warga pasamuan. Bagi warga pasamuwan bangunan gereja adalah tempat ibadah (GITJ Dermolo) berdasar pada surat IMB no. 648/150 tertanggal 9 Maret 2002, sedangkan FSMD menganggap bangunan GITJ Dermolo sebagai rumah tinggal Bapak Supardi. Selisih pemahaman tentang bangunan gereja itu berlanjut hingga penilitian ini dilakukan.

Setelah adanya surat pernyataan itu, warga pasamuwan tetap menjalankan aktivitas ibadahnya di rumah gubuk garasi yang terletak persis di belakang bangunan GITJ yang setengah jadi, sampai sekarang. Rumah gubuk garasi itu berlantai tanah merah, berdinding anyaman bambu (kepang/gedhek), beratap seng yang menurut warga pasamuwan sering bocor. Sementara bangunan GITJ

${ }^{11}$ FSMD (Forum Silaturrahmi Masyarakat Dermolo) adalah organisasi lokal Desa yang diinisiasi oleh masyarakat Desa Dermolo baik tokoh pemuda maupun yang tua untuk mengantisipasi setiap peristiwa yang terjadi di Dermolo bukan hanya yang berkaitan dengan dugaan bangunan untuk gereja. 
sendiri hanya bisa digunakan sebagai gudang tempat barang-barang rusak. Hal itulah yang menjadi pokok persoalan yang ditanggung warga pasamuwan Kristen desa Dermolo hingga sekarang. Sehubungan dengan lahirnya Peraturan Bersama Mentari (PBM) tahun 2006 sebagai hasil kesepakatan dan munculnya dari para tokoh 5 agama di Indonesia, maka sudah barang tentu segala sesuatunya merujuk kepada norma hukum tersebut, dengan tetap mengedepankan kearifan lokal. ${ }^{12}$

\section{PERAN FKUB KABUPATEN JEPARA}

Visi Forum Kerukunan Umat Beragama (FKUB), yaitu : “Optimalisasi suasana kerukunan hidup umat beragama di Kabupaten Jepara yang berperadaban maju dan modern, hidup sejahtera dunia dan akhirat dalam nuansa Kabupaten yang bersih, indah, aman dan nyaman sebagai wujud dari Jepara Kota Ukir". Sedangkan misinya adalah : 1) Mewujudkan masyarakat yang beriman, bertaqwa dan beramal sholeh; 2) Mewujudkan masyarakat untuk mengamalkan ajaran agamanya,yang taat hukum dan syari'atnya, bermoral dan berakhlak mulia; 3) Memantapkan kesadaran dan kegairahan masyarakat penuh kebersamaan dalam beramal sholeh dan amal sosial; 4) Mendorong berbagai usaha pengembangan lembaga-lembaga keagamaan merujuk suasana kerukunan hidup umat beragama yang lebih kondusif; dan 5) Memantapkan peran dan fungsi rumah-rumah ibadah bagi masyarakat/ umatnya. ${ }^{13}$

Berangkat dari visi dan misi tersebut, maka fungsi FKUB adalah : 1) Koordinatif, yang mengkoordinasikan tokoh agama dan tokoh masyarakat dalam melakukan dialog-dialog keagamaan; 2) Konsultatif \& Aspiratif, di antara lembaga-lembaga keagaman,masyarakat dan pemerintah; 3) Informatif, antara lembaga-lembaga keagaman/tokoh-tokoh agama serta memberikan penerangan,pencerahan dan pencerdasan kepada masyarakat; 4) Advokatif, melakukan persuasi keagamaan terhadap masyarakat, pemerintah dan pihak terkait; 5) Terwujudnya jaringan kebersamaan, saling pengertian,saling menghargai, toleransi antara lembaga-lembaga keagamaan menuju kerukunan hidup umat beragama lebih optimal; dan 6) Terwujudnya peningkatan kesadaran masyarakat akan ajaran agamanya, dan kapasitas dirinya sebagai warga beriman.

12 Selanjutnya simak, Hasil Kajian Forum Kerukunan Umat Beragama tertanggal 10 September 2012, Penulis kesaksian, Dr. H. Mashudi, M.Ag. (Sekretaris FKUB Kabupaten Jepara, yang sekarang beliau menjadi ketua forum resmi tersebut).

13 Simak Anggaran Dasar dan Anggaran Rumah Tangga Forum Kerukunan Umat Beragama (FKUB) Kabupaten Jepara masa khidmah : 2014-2019 
Selanjutnya, guna memperlancar beberapa gagasan tersebut, maka strategi yang dilakukan adalah : a) Melakukan sinergi dan kerjasama antara lembagalembaga keagamaan agar bisa lebih saling menguatkan; b) Menanamkan dan mengamalkan perilaku S5 (senyum, salam, sapa, sopan, santun); c) Kampanye/atau sosialisasi untuk membangkitkan kesadaran masyarakat khususnya dalam mewujudkan kerukunan hidup umat beragama, yang berarti "setuju dalam perbedaan". Adapun sasaran yang dijadikan obyek sasaran adalah : a) Teralisasinya sinergi program pemantapan usaha kerukunan hidup umat beragama melalui dialog dan kegiatan sosial keagamaan; b) Terealisasinya sistem administrasi pendapatan jumlah umat beragama dan rumah-rumah ibadah; c) Terwujudnya aturan dan ketentuan di daerah dalam memperkokoh dan memperlancar ketertiban,dan kelancaran pelaksanaan pengembangan dan ibadah bagi umatnya.

Sebagaimana disampaikan di atas, bahwa Kabupaten Jepara adalah suatu wilayah kabupaten dari sekian ribu kabupaten di Indonesia. Penelitian sejarah lokal maupun nasional yang menyinggung tentang Jepara, melaporkan bahwa sejak dahulu Jepara sudah dikenal sebagai wilayah yang senantiasa kondusif dan masyarakatnya saling mengedepankan kerukunan. Dalam titian sejarah berikutnya, kondisi di Kabupaten Jepara tersebut masih eksis. Suatu kewajiban bagi generasi berikutnya untuk tetap mengawal kondisi rukun tersebut dengan sungguh-sungguh dan dinamis.

Kurang lebih dalam kurun waktu lima tahunan, adalan dimana forum kerjasama antar umat beragama (FORKAB) kabupaten Jepara, sebagai satusatunya forum yang munculnya dari para tokoh umat beragama di kabupaten Jepara dan dilantik langsung oleh Menteri Agama, melakukan pengabdian kepada bumi pertiwi kendati hanya lokal Jepara, mengawal kerukunan. Beberapa bukti nyata peran tokoh agama melalui FORKAB yang mampu mengawal Jepara ini aman, dapat dikemukakan : pertama, pemilihan umum legislatif dan pemilihan umum Presiden/wakil Presiden tahun 2004 yang terlaksana dengan langsung, umum, bebas, dan rahasia, jujur, dan adil dalam suasana demokratis dan iklim kondusif. Semula semua orang meragukan apahak pemilihan umum akan berjalan dengan sukses ataukah justru sebaliknya. Kedua, pemilihan Kepala Daerah/Wakil kepala Daerah (pemiloihan Bupati/Wakil Bupati) jepara yang berlangsung dengan sukses, meskipun karena percaturan politik lokal, pelaksanaan pilkada harus diundur hingga dua kali. Namun toh munculnya adalah kearifan lokal. Ketiga, pemilihan petinggi se kabupaten jepara yang berlangsung tiga tahap berlangsung dengan sukses. 
Sekarang ini, oleh karena tuntutan SKB Menteri Agama dan Menteri Dalam Negeri, Forum Kerjasama Antar Umat beragama (FORKAB) kabupaten Jepara Harus berakhir dan diganti dengan Forum Kerukunan Antar umat Beragama (FKUB) kabupaten jepara.Secara substansial, pergantian wajah dari FORKAB menjadi FKUB tidak bnerbeda jauh. Artinya, banyak sisi yang seide dan sejalan dengan FKUB.Oleh karena itu nuasa FKUB harus mencerminkan nuansa FORKAB dalam berbagai hal termasuk kerukunan, komunikasi dan kerjasama antar para tokoh agama di kabupaten Jepara.Kebijakan FKUB kabupaten Jepara adalah kebijakan yang terkait dengan keberadaan FKUB sebagai lembaga dan forum yang dibentuk oleh masyarakat dan di fasilitasi oleh Pemerintah dalam rangka membangun, memelihara dan memberdayakan umat beragama untuk kerukunan dan kesejahteraan. Kebijakan FKUB kabupaten Jepara meliputi :Kebijakan Keadministrasian, ${ }^{14}$ Kebijakan Pengemban Tugas Amanat SKB. Sedangkan kebijakan sebagai pengemban tugas amanat SKB ${ }^{15}$ adalah kebijaka yang senantiasa merujuk kepada surrat keputusan bersama Menteri Agama dan Menteri Dalam Negeri No. 8 dan 9 tahun 2006 tentang pedoman pelaksanaan tuygas Kepala daerah/Wakil Kepala Daerah dalam pemeliharaan kerukuna umat beragama, pemberdayaan forum kerukunan umat beragama, dan pendiri rumah ibadat; Kebijakan Mengenai pendirian rumah ibadat, ${ }^{16}$ Kebijakan Merespom Aspirasi Masyarakat, ${ }^{17}$ dan Kebijakan-Kebijakan lain. ${ }^{18}$

14 Yang dimaksud kebijakan keadministrasian adalah proses penyelesaian tugas sebagaimana umumnya organisasi, seperti mengadakan rapat-rapat baik harian maupun pleno, ketertiban administrasi dan pelaporan

15 Sejalan dengan itu, kebijakan FKUB Kabupaten Jepara sebagai penggembang tugas amanat SKB meliputi : a. Melakukan dialog dengan pemuka Agama atau tokoh masyarakat; b. Menampung aspirasi Ormas keagamaan dan aspirasi masyarakat; c. Menyalurkan aspirasi ormas keagamaan dan masyarakat dalam bentuk aspirasi sebagai bahan kebijakan bupati; d. Melakukan sosialisasi peraturan perundangundangan dan kebijakan di bidang keagamaan yang berkaitan dengan kerukunan umat beragama dan pemberdayaan masyarakat; dan e. Memberikan rekomendasi tertulis atas permohonan pendirian rumah ibadat (simak pasal 9 ayat 2 SKB).

${ }^{16}$ Perihal yang terkait dengan pendirian rumah ibadat diatur sebagai berikut :a. Pendirian Rumah ibadat didasarkan pada kepearluan nyata dan sungguh-sungguh berdasarkan komposisi jumlah penduduk bagi pelayanan umat beragama yang bersangkutan di wilayah kelurahan atau desa; b. Pendirian rumah ibadat tetap harus menjaga kerukunan umat beragama tidak mengganggu ketentraman dan ketertiban umum serta mematuhi peraturan perundang-undangan dalam hal keperluan nyata bagi pelayanann umat beragama di wilayah kelurahan atau desa tidak terpenuhi, pertimbangan komposisi jumlah penduduk digunakan batas wilayah kecamatan atau kabupaten atau 


\section{METAMORFOSIS FORKAB ${ }^{19}$ KE FKUB}

Setiap orang menjalankan ibadah berdasarkan pada ajaran agamanya, undang-undang dasar 1945 memberikan jaminan terhadap kebebasan itu berdasarkan pasal 29 ayat (2).Terkait dengan aktifitas relasi sosial atau lalu lintas hubungan antar umat agama, pemerintah mempunyai kewajiban untuk melakukan pengarturan agar tetap terjaga ketertiban, ketentraman dan kesejahteraan masyarakat seperti pengaturan tentang pendirian rumah ibadat, tidak terkait dengan aqidah.

Contoh pada tanggal 21 maret 2006 telah ditanda tangani peraturan bersama menteri agama dan menteri luar negeri nomor: 9 tahun 2006 dan No: 8 tahun 2006 tentang PedomanPelaksanan Tugas Kepala Daerah/ Wakil Kepala Daerah dalam Pemeliharaan Kerukunan Umat Beragama, Pemberdayaan FKUB dan Pendirian Rumah Ibadat.Peraturan Bersama tersebut disusun dan dirumuskan dengan melibatkan wakil dan Majelis-Majelis Agama Tingkat Pusat MUI, PGI, KWI, PHDI dan WALUBI.

kota atau profinsi. (simak pasal $13 \mathrm{SKB}$ ); c. Pendirian rumah ibadat harus memenuhi persyaratan teknis bangunan gedung; d. Pendirian rumah ibadat harus memenuhi persyaratan khusus meliputi : 1. Daftar nama dan kartu tanda penduduk penggunaan rumah ibadat paling sedikit 90 oarang yang disahkan oleh pejabat setempat sesuai dengan batas wilayah. 2. Didukung masyarakat setempat paling sedikit 60 orang yang disahkan oleh lurah atau kepala desa. 3. Rekomendasi tertulis kepada kantor Departemen Agama Kabupaten dan rekomendasi FKUB kabupaten (simak pasal 14). 4. Rekomendasi FKUB merupakan hasil musyawarah mufakat dalam rapat FKUB, dituangkan dalam bentuk tertulis (simak pasal 15). 5. Permohonan pendirian rumah ibadat diajukan oleh panitia pembangunan rumah ibadat kepada Bupati untuk memperoleh IMB rumah ibadat. 6. Bupati memberikan keputusan paling lambat 90 hari sejak permohonan pembangunan rumah ibadat diajukan. (simak pasal 16). 7. Pemerintah daerah memfasilitasi penyediaan lokasi baru bangunan gedung rumah ibadat uang telah memiliki IMB yang dipindahkan karena perubahan rencana tata ruang wilayah.

${ }^{17}$ Seperti a). Kebijakan yang diberikan FKUB Kabupaten Jepara dalam merespon aspirasi baik dalam berupa saran, usulan dan kritik tidak boleh bertentangan dengan SKB dan dilakukan melalui FKUB; b). Kebijakan yang diberikan FKUB kabupaten Jepara secara substansial tiidak boleh menyangkut masalah akiidah (keyakinan).

${ }^{18}$ Kebijakan lain tersebut harus didasari atas asas manfaat secara organisatoris kepada FKUB dan tikak berseberangan dengan SKB; dan Kebijakan apapun senantiasa merujuk pada SKB.

19 Forum Kerjasama Antar Umat Beragama (FORKAB) adalah nama suatu perkumpulan lima agama yang di Indonesia yang juga ada di Kabupaten Jepara. Forum ini berdiri atas inisiatif Departemen Agama dan disetujui oleh Bupati Jepara. Barangkali Forum ini satu-satunya Forum lokal (bentukan lokal/inisiatif daerah) yang dilantik langsung oleh Menteri Agama (Prof. Dr. KH. Said Aqil al-Munawar, MA) di Ponpes Balekambang pada tahun 2002. 
Memang secara kronologis sejak tahun 1969 Pemerintah telah menerbitkan SKB Menteri Agama dan Menteri Dalam Negeri Nomor: 1/BER/ MDN-MAG/1969 yang mengatur perihal Pendirian Rumah Ibadat. Adapun Pasal yang mengatur Pendirian Rumah Ibadat ialah Pasal 4 yaitu:

1) Setiap pendirian Rumah Ibadat perlu mendapatkan ijin dari kepala Daerah atau pejabat pemerintahan dibawahnya yang dikuasakan untuk itu.

2) Kepala Daerah atau Pejabat yang dimaksud dalam ayat 1 pasal ini memberikan ijin yang dimaksud, setelah mempertimbangkan:

a) Pendapa Kepala Perwakilan Departemen Agama setempat

b) Planologi

c) Kondisi dan keadaan setempat

3) Apabila dianggap perlu, Kepala Daerah atau Pejabat yang ditunjuknya itu dapat meminta pendapat dari organisasi-organisasi keagamaan dan ulama/ rohaniawan setempat.

Pada akhir tahun 2004 ada tuntutan untuk mencabut SKB tersebut, dan terjadi polemik mempermasalahkan SKB tersebut, yang bagi sebagian kelompok Umat Beragama dianggap menghambat pendirian rumah Ibadat.Mencermati keadaan tersebut, Presiden RI memerintahkan Menteri Agama dan Menteri Dalam Negeri untuk merespon pro-kontra itu dengan melakukan langkahlangkah yang dianggap perlu.Pemerintah melakukan kajian ulang terhadap SKB tersebut, hasilnya antara lain; 1) SKB tersebut masih relevan karena masalah pendirian rumah ibadah menjadi salah satu sebab yang dapat menggangu hubungan antara umat beragama sehingga perlu diatur. 2) Ternyata jumlah rumah ibadah semua kelompok agama yang ada di Indonesia setelah SKB No: 1 tahun 1969 diberlakukan, berkembang dengan pesat. Apabila kita bandingkan dengan keagaam tahun 1977 dan 2004 ternyata rumah ibadah bertambah jumlahnya : a) Rumah ibadah islam dari 392.044 pada tahun 1977 menjadi 643.834 pada tahun 2004 (kenaikan sebesar $64 \%$ ); b) Rumah ibadah Kristen bertambah jumlahnya dari 18.977 pada tahun 1977 menjadi 43.909 pada tahun 2004 (kenaikan sebesar 131\%); c) Rumah ibadah Katholik bertambah jumlahnya dari 4.934 pada tahun 1977 menjadi 12.473 pada tahun 2004 (kenaikan sebesar 153\%); d) Sedangkan rumah ibadah Budha bertambah jumlahnya dari 1.523 pada tahun 1977 menjadi 7.129 pada tahun 2004 (kenaikan sebesar 369\%). Data tersebut telah diverifikasikan denga Dirjen Bimas Islam dan Penyelenggaraan Haji, Dirjen Bimas Kristen, Dirjen Bimas Khatolik, serta Dirjen Bimas Hindu Dan Budha. 
Selanjutnya, pada tanggal 7 september tahun 2005 telah dilakukan rapat bersama antara Menteri dalam Negeri, Menteri Agama, Jaksa Agung, Kapolri, Menteri Hukum dan HAM, dan sejumlah pejabat lainnya untuk membahas penyempurnaan SKB tersebut. Rapat menyimpulkan bahwa SKB tersebut perlu disempurnakan supaya mengacu pada undang-undang Nomor 32 tahun 2004. Kemudian mulai tanggal 12 September tahun 2005 diadakan rapat-rapat setingkat eselon I Departemen Agama dan Departemen dalam Negeriuntuk menyusun draf penyempurnaan. Dilingkungan internal Departemen Agama sendiri telah dilakukan sejyumlah pertemuan dengan seluruh pejabat eselon I khususnya para Dirjen Bimas untuk menyiapkan draf awal tersebut.

Pada awal Oktober 2005, draf penyempurnaan SKB yang dihasilkan Departemen Agama dan Departemen dalam Negeri telah siap untuk dibahas dengan majelis-majelis Agama. Adapun pembahasan draf tersebut dengan wakil majelis agama sendiri berlangsung mulai bulan Oktober 2005 sampai dengan 30 Januari 2006 sedangkan pembahasan kesebelas (terakhir) dilakukan dengan Majelis agama tanggal 21 Maret 2006 dan dihadiri langsung oleh Menteri Agama dan Menteri Dalam Negeri.

Secara umum dapat dikatakan bahwa proses pembahasan itu telah berjalan dengan insentif, terbuka, dan bersifat kekeluargaan.Semua rumusan yang dibahas mencapai titik temu sebagai jalan keluar berkat kelapangan dada dan kebesaran jiwa masing-masing pemuka agama yang mewakili majelis-majelis Agama.Sehingga inti PBM memuat 3 pedoman pokok yaitu pedoman tentang langkah-langkah Kepala Daerah/Wakil Kepala Daerah antara lain: a) Pemeliharaan Kerukunan Umat Beragama sebagai bagian penting dari kerukunan nasional; b) Pemberdayaan FKUB; c) Pendirian Rumah Ibadat.

Sesungguhnya sasaran yang hendak dicapai PBM adalah tidak terlepas dari Visi dan Misi Pembangunan Nasional, dimana Visi dan Misi Pembangunan Nasional 2004-2009 atau visi Kabinet Indonesia Bersatu Jilid I dan II yaitu: 1) Terwujudnya kehidupan masyarakat, bangsa, dan negara yang aman, bersatu, rukun dan damai; 2) Terwujudnya masyarakat, bangsa dan negara yang menjunjung tinggi hukum, kesetaraan, dan hak asasi manusia; serta 3) Terwujudnya perekonomian yang mampu menyediakan kesempatan kerja dan penghidupan yang layak serta memberikan pondasi yang kokoh bagi pembangunan berkelanjutan.Selanjutnya, derdasarkan visi pembangunan nasional tersebut ditetapkan tiga misi pembangunan nasional tahun 2004-2009, yaitu: 1) Mewujudkan Indonesia yang aman dan damai; 2) Mewujudkan Indonesia yang adil dan demokratis; serta; 3) Mewujudkan Indonesia yang sejahtera. 
Dengan mengacu pada visi dan misi pembangunan nasional tahun 20042009, maka Kementerian Agama menetapkan visinya sebagai berikut:Terwujudnya masyarakat Indoonesia yang taat beragama, maju, sejahtera, dan cerdas serta saling menghormati antar sesama pemeluk agama dalam kehidupan bermasyarakat, berbangsa dan bernegara dalam wadah Negara Kesatuan Republik Indonesia. Berkaitan dengan itu pula Kementerian Agama menetapkan misinya sebagai berikut: 1) Meningkatkan kualitas bimbingan, pengalaman, dan pelayanan kehidupan beragama; 2) Meningkatkan penghayatan, moral dan etika keagamaan; 3) Meningkatkan kualitas pendidikan umat beragama; 4) Meningkatkan kualitas penyelenggaraan Haji; 5) Memperkokoh kerukunan umat beragama; dan 6) Mengembangkan keselarasan pemahaman keagamaan dengan wawasan kebangsaan Indonesia.

Dengan demikian sasaran yang hendak dicapai dengan PBM tersebut adalah untuk meningkatkan kerukunan hidup umat beragama dengan meningkatkan rasa saling percaya dan harmonis antar kelompok sehingga tercipta suasana kehidupan masyarakat yang penuh toleransi, tenggang rasa, dan harmonis untuk mencapai tujuan pembangunan nasional yang aman, damai, dan sejahtera.

Terwujudnya masyarakat Indonesia yang taat beragama, maju, sejahtera, cerdas, serta saling menghormati antar sesama pemeluk agama dalam kehidupan bermasyarakat, berbangsa, dan bernegara dalam wadah Negara Kesatuan Republik Indonesia. Dalam rangka itu, selayaknyalah kita semua bersinergi mencari solusi untuk mengisi dan mempercepat pencapaian cita-cita kemerdekaan bangsa yang telah kita raih sejak 75 tahun yang lalu. Namun, kita akui bahwa kemerdekaan bangsa ini belum sepenuhnya dapat kitaimplementasikan dalam bentuk kejayaan dan kemajuan umat secara luas dan merata.

Banyak kendala yang dihadapi bangsa untuk mengisi kemerdekaan yang susah payah diraih tersebut. Antara lain betapa sulitnya kita memadukan berbagai potensi untuk menegakkan kemandirian bangsa. Bahkan, janganlah untuk memadukan potensi, untuk menghindar dari pertikaian-pertikaian yang tidak perlu, rasanya masih sulit dilakukan. Itulah sebabnya, pemerintah ingin mengajak segenap komponen bangsa untuk menyadari bahwa PBM No. 9 dan 8 Tahun 2006 adalah merupakan momentum yang baik dan tepat untuk kita gunakan sebagai upaya untuk memperbaiki kondisi yang kurang pada masa lalu. Dalam kaitan ini, perlu kita renungkan bersama sejauh mana kebersamaan sebagai umat selama ini dapat kita galang secara konkret guna membangun sebuah bangsa yang kuat, maju dan jaya. Melalui PBM No. 9 dan 8 tersebut, kita 
perlu lebih mempertebal kayakinan bahwa kejayaan suatu bangsa sangat dipengaruhi oleh peran dan kebersamaan umat beragama. Boleh jadi, belum berhasilnya kita meraih kejayaan setelah sekian puluh tahun merdeka karena memang belum satu padunya umat dalam melangkah serta membangun segenap potensi bangsa.

Umat beragama dewasa ini, disadari atau tidak, suka atau tidak suka, tengah berhadapan dengan berbagai persoalan, baik yang menyangkut internal maupun eksternal umat. Suatu hal yang tidak dapat dipungkiri, bahwa apapun persoalan yang dihadapi umat beragama hari ini, tidak terlepas dari perkembangan dan dinamika dunia luar yang secara tidak langsung turut pula mewarnai sikap keberagaman masyarakat. Persoalan-persoalan yang menyangkut problem sosial, persoalan Hak Asasi Manusia, Harmonisasi Sosial, bahkan pemahaman dan praktek-praktek keagamaan turut mempengaruhi umat beragama dan pada akhirnya melibatkan pemerintah untuk mengambil berbagai kebijakan sebagai jalan keluar. Ini merupakan salah satu konsekuensi hidup di era pluralistik ini.

Awal tahun 1990 futurolog John Naisbit dan Patricia Aburdene, telah memprediksi bahwa memasuki abad 21 dunia akan menghadapi dasawarsa penting dalam sejarah peradaban manusia karena empat hal: pertama, perkembangan teknologi informasi, kedua pasar bebas, ketiga reformasi politik, dan keempat kelahiran kembali kultur yang besar. Negara-negara maju sebagai penguasa teknologi informasi dan komunikasi sekaligus pula menjadi lokomotif dibidang ekonomi, politik, kultur dan sebagainya. Akibatnya, negara-negara berkembang rela atau tidak rela, harus puas menerima posisi sebagai negara yang terus tergantung pada negara maju. Kondisi kehidupan global memaksa kita harus menerima posisi kehidupan demikian. Dalam realita kehidupan global, hukum alam yang kaut "yang kuat memangsa yang lemah" tetap tidak dapat terelakkan, bahkan menurut pandangan para pakar, sampai pada soal menentukan tensi politik dalam negeri di negara-negara "lemah" para negara maju sering ikut terlibat.

Memahami betapa kompleksnya persoalan umat beragama pada era global ini, maka seyogianyalah kita ucapkan penghargaan setinggi-tingginya kepada segenap majelis agama yang dengan kekompakan serta jiwa kebersamaan dan semangat kebangsaan yang tinggi telah berhasil merumuskan berbagai kesepakatan sebagaimana tertuang dalam PBM No. 9 dan 8 tahun 2006. Sebagaimana kita ketahui bahwa substansni penting PBM tersebut adalah mengenani "Pedoman Pelaksanaan Tugas Kepala Daerah/Wakil Kepala Daerah 
dalam memelihara Kerukunan Umat Beragama, Pemberdayaan Forum Kerukunan Umat Beragama, dan pendirian Rumah Ibadat."

Ketiga substansi tersebut merupakan komponen penting dan saling berkaitan. Jika komponen pertama merupakan pedoman bagi petugas aparat pemerintah dalam merealisasikan komponen kedua dan ketiga, maka komponen kedua dan ketiga memerlukan perhatian dan dukungan segenap unsur umat dan masyarakat agar dapat terealisasi secara baik tugas-tugas aparat pemerintah dimaksud. Dengan itu pula, maka kehadiran FKUB sebagai pendorong dinamisnya PBM dipandang penting dan strategis. Sesuai ayat 6 pasal 1, fungsi forum adalah untuk membangun, memelihara, dan memberdayakan umat veragama untuk kerukunan dan kesejahteraan. Dengan demikian pembahasan lokakarya ini terhadap implementasi PBM No. 9 dan 8Tahun 2006 dipandang tepat guna merespon persoalan-persoalan umat dan bangsa dimasa sekarang dan akan datang.

Seiring dengan dinamika kehidupan global yang penuh tantangan di satu sisi, dan adanya keinginan bangsa untuk berubah menjadi bangsa yang lebih maju dan besar di masa yang akan datang, maka dadri sudut perang umat beragama, mau tidak mau tampaknya memang harus dilakukan reposisi hubungan umat beragama kearah yang lebih baik kedepan. Dalam konteks ini kerukunan bukan hanya sekedar toleran atau tidak saling mengganggu, melainkan akibat kemajuan teknologi, perkembangan ekonomi, mobilitas penduduk, persaingan internasional dan perubahan lingkungan hidup, maka FKUB perlu mengembangkan hubungan umat beragama kearah yang lebih kokoh dan genuine melalui kerjasama konkrit dalam berbagai aspek kehidupan sosial. Selain itu, peran FKUB juga sangat penting untuk memberikan pencerahan kepada masyarakat sehingga umat beragama dalam konteks kehidupan berbangsa memperoleh arah yang jelas kemana harus berjalan. Untuk itu, sebagai langkah awal, pembentukan FKUB di seluruh Provinsi serta Kabupaten/kota mutlak dilakukan sebagaimana diamanahkan oleh PBM itu sendiri.

Dalam kesempatan ini pula, kami menhimbau segenap peserta bahwa dalam rangka mencari yang terbaik buat bangsa, kita perlu mengurangi rasa curiga yang berlebihan diantara sesama kita. Kita harus lebih mengedepankan problem bersama yang kita sebut sebagai problem umat beragana. Karenanya, kita perlu kata sepakat atas penyelesaian problem umat yang mendesak, seperti kemiskinan, kebodohan, mengatasi berbagai penyakit-penyakit sosial yang diperlukan umat saat ini. Untuk itu diperlukan kearifan semua pihak, baik kearifan yang bersifat universal maupun spiritual. Bila kearifan-kearifan tersebut 
dapat dirumuskan dalam lokakarya ini, maka sudah barang tentu merupakan modal yang berharga dalam membina kehidupan umat yang harmonisdi tengahtengah masyarakat. Perspektif kearifan-kearifan seperti itu pulalah yang kita harapkan dapat mendorong kepekaan yang tinggi pada segenap umat untuk lebih tergugah dan lebih peduli akan nasib sesama anak bangsa.

Sebegaimana disebutkan di atas, Indonesia sebagai sebuah negarakesatuan merupakan negara majemuk yang terdiri dari beribu-ribu pulauyang di dalamnya terdapat multi agama, multi etnis, multi ras dan multikultur. Kemajemukan tersebut di satu sisi menjadi kekuatan dari bangsa ini;karena bisa menjadi nilai lebih untuk memperkaya bangunan fondasinasionalisme bangsa. ${ }^{20}$ Namun di sisi lain kemajemukan juga dapatberpotensi menjadi ancaman yang serius bagi integrasi nacional jika terjadidisharmoni. Karenanya, segala upaya untuk mewujudkan harmoni danintegrasi nasional seharusnya tidak qkan pernah berhenti diupayakan.Hanya saja, fakta sejarah berbicara lain. seoptimal apapun upaya yangtelah dilakukan untuk membangun harmoni dan mencegah adanyadisintegrasi bangsa, ada saja ancaman terhadap integrasi nasional yangkadang-kadang muncul dalam bentuk pemberontakan, gerakan pemisahandiri (separatisme) maupun konflik antar-kelompok masyarakat atau antarakelompok masyarakat dengan pemerintah.

Memang harus pula diberikan catatan, bahwa disharmoni dandisintegrasi yang pernah muncul bukan semata disebabkan oleh adanyakemajemukan dalam hal suku, ras, budaya maupun agama, akan tetapilebih banyak dipengaruhi oleh latar belakahg politik ataupun ekonomi.Upaya untuk menekan hal tersebut juga telah dilakukan oleh pemerintah.Bahkan sejarah mencatat, pada masa Orde Baru, upaya tersebut dilakukan

dengan sangat rigid karena lebih berorientasi pada pendekatan keamanan(security approach), dimana semua ekspresi atau tindakan warga negarayang dianggap dapat menimburkan problem SARA (suku, agama, ras danantar-golongan) ditekan secara keras, karena dikhawatirkan akan berimbaspada disintegrasi. Pendekatan yang agak berbeda diberlakukan setelah

${ }^{20}$ DR. KH. Ma'ruf Amin, Ketua Maielis Ulama Indonesia (MUI) Pusat, Anggota Dewan Pertimbangan Presiden Bidang Hubungan Antar Agama, dalam makalah berjudul "Peran Lembaga Keagamaan dalam Menciptakan Kehidupan Keagamaan yang Harmonis : Perspektif Agama", Disampaikan dalam acara Halaqah Ulama "Optimalisasi Peran Lembaga Keagamaan dalam Pelayanan Umat", Kerjasama Direktorat Jenderal Binmas Islam Kemenag RI dan Majelis Ulama Indonesia Provinsi Jawa Tengah di Semarang, pada tanggal 21 September 2012. 
erareformasi, yaitu dengan menggunakan pendekatan yang lebih demokratisdengan menjamin ekspresi kebebasan yang lebih substantif.

Kemajemukan yang terjadi di Desa Dermolo tidak perlu untuk dihilangkan, karena merupakan realita yang tidak dapat dihindarkan. Setiapupaya untuk menghapus kemajemukan yang ada merupakan upaya yangsia-sia, karena bertabrakan dengan realita yang ada. Kemajemukan yangada bukan untuk dihapuskan, tapi harus dikelola dengan baik dan benar.oleh karenanya, menurut hemat saya, diperlukan adanya dialog yangberkelanjutan dan dilandasi adanya kejujuran di antara komponenmasyarakat, terutama antar pemeluk agama. Dialog yang berkejujuran inidiharapkan dapat mengurai permasalahan yang selama ini mengganjal dibenak masing-masing kelompok di masyarakat. Mungkin saja masalahyang selama ini terjadi di antara pemeluk agama, atau di antara pemelukagama yang berbeda faham, muncul karena tidak sampainya informasiyang benar dari satu pihak ke pihak lainnya. Terputusnya jalinan informasiantar kelompok dalam masyarakat dapat menimbulkan prasangka prasangka yang mengarah pada terbentuknya penilaian negatif. Olehkarenanya, dialog yang berkejujuran di antara komponen masyarakat,khususnya antar pemeluk agama, atau antar pemeluk agarna yang berbedafaham, mutlak diperlukan.

Disamping itu, dalam membangun harmoni perlu juga adanya suatukoridor yang membingkai kemajemukan yang ada agar tidak menjadipotensi konflik dan disintegrasi. Bingkai kemajemukan yang diperlukantersebut baik yang bersifat politis, yuridis, sosiotogis dan yang tidak kalahpentingnya adalah bingkai teologis.Bila didekati secara politis, sejarah telah mencatat, bangsa ini telah mengambil kebijakan politikbahwa bentuk dari negara-bangsa ini adalah Negara Kesatuan Republiklndonesia (NKRI) dengan Pancasila sebagai falsafah bangsa dan UUD45 sebagai konstitusi negara-bangsa ini.

Para bapak pendiri republik (founding fathers) sepakat menjadikannegara ini sebagai Negara Kesatuan Republik Indonesia (NKRI), denganwilayah yang membentang dari Sabang sampai Merauke. Karena dalamNKRI ini terdapat berbagai macam kelompok masyarakat, baik dari segisuku, agama, budaya maupun ras, maka para pendiri republik itumengidealisasikan bangsa lndonesia ini sebagai sebuah bangsa yangmajemuk, tetapi tetap satu, dengan semboyan "bhinneka tunggal ika".Dalam sebuah negara yang masyarakatnya majemuk, adalah tidakmudah untuk mewujudkan persatuan dan kesatuan bangsa ini, karenamasing-masing kelompok memiliki kepentingan dan aspirasi yangbervariasi, yang bisa menimbulkan konflik di antara mereka. 
Namundemikian melalui slogan tersebut diharapkan menumbuhkan kesadarandi antara masyarakat di Indonesia akan pentingnya harmoni dalamberbangsa, bernegara dan bermasyarakat.Artinya, harmoni yang terjadi di negara ini tidak terlepas dariadanya ikatan politis yang membingkai hubungan antar komponenwarga bangsa, yakni: (1) Negara Kesatuan Republik Indonesia (NKRI),(2) Undang-Undang Dasar 1945, (3) Pancasila, dan BhinnekaTunggal lka.

Contoh berikut merupakan upaya FKUB Kabupaten Jepara meneduhkan kerukunan umat beragama :

"Sehubungan dengan menyambut Tahun Baru Islam 1 Muharram 1430 H, Perayaan Natal dan Tahun 2009 M, maka Forum Komunikasi Umat Beragama (FKUB) Kabupaten Jepara menerbitkan pesan-pesan sebagai berikut : Pertama,Selaku umat beragama, agar di penghujung tahun ini senantiasa melakukan evaluasi baik secara individual maupun kolektif, melakukan perbaikan dan meningkatkan kualitas iman serta menghindari perilaku yang bertentangan dengan doktri agama itu sendiri; Kedua, Bertekad mempertebal keimanan sebagai modal dasar guna mewujudkan kerukunan hidup beragama, mempererat tali persaudaraan dan memupuk kebersamaan, persatuan dan kesatuan untuk mengarungi kehidupan sebagai sebuah bangsa di tengah-tengah kehidupan global; Ketiga, Bersikap, bertindak, dan bertingkah laku positif guna meraih kebajikan dan kemaslahatan, kecermatan dan kewaspadaan serta tidak mudah terprovokasi untuk hal-hal yang bernuansa negatif. Demikian mudah-mudahan pesan-pesan ini direspon dengan baik, diimplemetasikan dengan penuh kesadaran demi kemaslahatan bersama, amin." ${ }^{21}$

"Sehubungan dengan menyambut Tahun Baru Islam 1 Muharram 1430 H, Perayaan Natal dan Tahun 2010 M, maka Forum Komunikasi Umat Beragama (FKUB) Kabupaten Jepara menerbitkan pesan-pesan sebagai berikut : Pertama,Selaku umat beragama, agar di penghujung tahun ini senantiasa melakukan evaluasi baik secara individual maupun kolektif, melakukan perbaikan dan meningkatkan kualitas iman serta menghindari perilaku yang bertentangan dengan doktri agama itu sendiri; Kedua, Bertekad mempertebal keimanan sebagai modal dasar guna mewujudkan kerukunan hidup beragama, mempererat tali persaudaraan dan memupuk kebersamaan, persatuan dan kesatuan untuk

${ }^{21}$ Pesan damai ini ditandatangani di Jepara, 25 Dzul Hijjah 1429 H/23 Desember 2009 M oleh Forum Kerukunan Umat Beragama Kabupaten Jepara, Ketua (Drs. KH. Chumaidurrohman ) dan Sekretaris (H. Mashudi, M.Ag.). 
mengarungi kehidupan sebagai sebuah bangsa di tengah-tengah kehidupan global; Ketiga, Bersikap, bertindak, dan bertingkah laku positif guna meraih kebajikan dan kemaslahatan, kecermatan dan kewaspadaan serta tidak mudah terprovokasi untuk hal-hal yang bernuansa negatif. Demikian mudah-mudahan pesan-pesan ini direspon dengan baik, diimplemetasikan dengan penuh kesadaran demi kemaslahatan bersama, amin."22

"Sehubungan dengan Peringatan Natal dan Tahun Baru 2011 bagi umat Kristiani khususnya di Kabupaten Jepara, maka Forum Komunikasi Umat Beragama (FKUB) Kabupaten Jepara menyerukan hal-hal sebagai berikut : 1) Mengajak setiap warga masyarakat di Kabupaten Jepara, sebagai umat beragama, untuk hormat menghormati umat penganut agama lain untuk menjalankan ibadah, merayakan dan memperingati hari-hari besar dan ritual sesuai dengan agamanya; 2) Mengajak setiap masyarakat di Kabupaten Jepara, sebagai umat beragama, untuk senantiasa mengedepankan persatuan dan kesatuan sebagai implementasi nilai luhur agama, di bawah naungan panji-panji Pancasila dan UUD 1945 guna memperkokoh Negara Kesatuan Republik Indonesia (NKRI); 3) Mengajak setiap masyarakat di Kabupaten Jepara, sebagai umat beragama, untuk mewujudkan toleransi Tri Kerukunan Umat Beragama dan tidak mudah terprovokasi oleh oknum yang tidak bertanggungjawab; 4) Mengajak setiap masyarakat di Kabupaten Jepara, sebagai umat beragama, membantu Pemerintah dalam upaya mewujudkan kondisi Kabupaten Jepara yang kondusif, aman, nyaman, dalam suasana demokratis; 5) Mengajak setiap masyarakat di Kabupaten Jepara, sebagai umat beragama, membantu Penegak hukum dan keamanan dalam upaya penegakan hukum dan keamanan dalam wujud turutserta menciptakan suasana aman dan damai di lingkungan masing-masing.Akhirnya, mudah-mudahan Allah SWT, Tuhan serusekalian alam, meridlai upaya kita semua, amïn."23

"Dengan hormat, Pada kesempatan yang berbahagia ini, selaku Ketua Forum Kerukunan Umat Beragama (FKUB) Kabupaten Jepara, saya mengajak kepada Bapak/Ibu/Saudara untuk senantiasa memanjatkan puji syukur kehadirat Tuhan Yang Maha Kuasa atas berbagai limpahan rahmat, nikmat dan hidayah kepada kita sekalian. Memenuhi surat permohonan Panitia Peresmian Paroki Stella Maris dan Gereja ST.

22 Pesan damai ini ditandatangani di Jepara, 25 Dzul Hijjah 1430 H/22 Desember 2010 M oleh Forum Kerukunan Umat Beragama Kabupaten Jepara, Ketua (Drs. KH. Chumaidurrohman ) dan Sekretaris (H. Mashudi, M.Ag.)

23 Seruan Forum Kerukunan Umat Beragama Kabupaten Jepara tentang Peringatan Natal 2010 dan Tahun Baru 2011 M. 
Theresia Avilla Pecangaan, nomor : 09/PAN-PSM/III/2008 tanggal 19 Maret 2008 perihal sebagaimana dalam pokok surat, maka perkenankan saya selaku Ketua FKUB Kabupaten Jepara menyampaikan hal-hal sebagai berikut :

1. Mengucapkan terima kasih kepada seluruh panitia peresmian, oleh karena FKUB Kabupaten Jepara mendapatkan penghormatan berupa memberikan kata sambutan.

2. Mengucapkan selamat atas peresmian Paroki Stella Maris dan Gereja ST. Theresia Avilla Pecangaan dengan harapan semoga benar-benar dimanfaatkan dan difungsikan sebagaimana mestinya, yang pada gilirannya mampu menunjang bagi upaya menciptakan iklim kondusif.

3. FKUB Kabupaten Jepara berharap agar jemaat Paroki Stella Maris dan Gereja ST. Theresia Avilla Pecangaan sebagai salah satu bagian dari pluralitas kehidupan umat beragama di Kabupaten Jepara, mampu menerapkan nilai-nilai agama dengan sebaik-baiknya, berbuat dengan mengedepankan prosedur hukum dan peraturan yang berlaku, menyikapi semua permasalahan yang muncul secara jernih serta mengedepankan kearifan lokal.

4. FKUB Kabupaten Jepara juga berharap agar jemaat Paroki Stella Maris dan Gereja ST. Theresia Avilla Pecangaan khususnya, tidak mudah terkontaminasi dengan berbagai fitnah yang sengaja ditebarkan oleh oknum yang tidak bertanggungjawab, karena sesungguhnya fitnah lebih kejam dari pembunuhan, termasuk munculnya film FITNA karya salah satu Angota Parlemen Belanda yang secara substansial muatannya merugikan umat lain.

5. Seiring dengan kondisi perkembangan kehidupan keberagamaan global sebagaimana yang kita saksikan sekarang ini, FKUB Kabupaten Jepara senantiasa mendukung wujudnya dialog peradaban dunia, khususnya antara Islam dengan Kristen yang menurut rencana akan digelar di Vatikan pada Bulan Nopember 2008 yang akan datang.

Demikian, semoga harapan tersebut di atas sungguh menjadi kenyataan berkat upaya keras dan konsisten oleh semua pihak serta pada gilirannya mampu menopang program pemerintah dalam melanjutkan pembangunan di segala bidang. ${ }^{24}$

\section{BEBERAPA PENDEKATAN}

${ }^{24}$ Sambutan Ketua Forum Kerukunan Umat Beragfama Nomor : 002/FKUBJPR/IV/2008 pada Peresmian Paroki Stella Maris dan Gereja ST. Theresia Avilla, Pecangaan, 6 April 2008 
Ada banyak jalan yang bisa dipakai dalam menjaga hubungan harmoni antar agama yang hidup berdampingan. Pertama, pendekatan teologis. Pendekatan teologis dari masing-masing agama diharapkan dapat menjadi perekat sehingga muncul harmoni dan saling memahami di antara parapemeluk agama. Landasan teologis dari masing-masing agama dapat dijadikan upaya untuk menumbuhkan harmoni di antara pemeluk agamadan sekaligus menjaga keutuhan dan kesatuan nasional.

Untuk mewujudkan integrasi nasional diperlukan kehidupan yangharmonis antar seluruh warga negara, walaupun berbeda agama, rasdan sukunya. Kehidupan yang harmonis ini akan mewujudkan stabilitasnasional yang kokoh, dan hal ini akan sangat kondusif bagi kelancaranpembangunan di bidang ekonomi dan sosial budaya secara umum. Halini akan terwujud, jika seluruh warga negara menyadari perlunyatoleransi (tasamuh) akan keragaman masyarakat Indonesia. Tanpaadanya toleransi ini kehidupan yang harmonis (rukun) sulit terwujud; dansebaliknya, yang terjadi adalah konflik antar kelompok masyarakat yangsebenarnya tidak diinginkan oleh setiap orang.

Konflik dan kekerasan ini sebenarnya tidak dibenarkan oleh agama,karena semua agama yang ada di lndonesia mengajarkan kebaikan dankedamaian hidup manusia. Buddha mengajarkan kesederhanaan,Kristen mengajarkan cinta kasih, Konghucu mengajarkan kebijaksanaan,dan lslam mengajarkan kasih sayang bagi seluruh alam (rabmatan lil'alamin) dan kesadaran untuk menjunjung tinggi kesepakatan nasional(mu'ahadah wathaniyah).Di kalangan umat lslam, landasan teologis ini sudah dihayati sedemikianrupa, sehingga muncul kesepakatan di antara umat lslam bahwa dalamberbangsa dan bernegara, Pancasila merupakan falsafah, dan bentuknegara ini adalah Negara Kesatuan Republik lndonesia. Sehinggaupaya separatisme atau pemisahan diri dari NKRI oleh umat lslamdianggap sebagai pemberontak yang harus ditumpas, yang dalam lslamdisebut sebagai bughat yang harus diperangi.

Dalam konteks berbangsa dan bernegara, lslam memosisikan umatagama lain dengan istilah mu'ahadah atau muwatsaqah, artinya sesamabagian warga bangsa yang terikat oleh komitmen kebangsaan sehinggaharus hidup berdampingan secara damai, bukan posisi muqatalah ataumubarabah, artinya kelompok lain yang harus diperangi. Sehinggadalam perspektif lslam, kelompok umat agama lain adalah merupakansama-sama warga bangsa yang tidak boleh diperangi atau dimusuhi.Bahkan ada sebuah hadis Nabi yang menyatakan bahwa barangsiapayang membunuh non muslim yang hidup berdampingan secara damai(mu'ahadah) maka tidak akan memperoleh bau sorga. Landasanteologis perspektif lslam dalam merajut kebersamaan berbangsa danbernegara ini, saya 
kira, juga di ajarkan oleh agama-agama lainnya.sehingga landasan teologis ini seharusnya menjadi acuan dalamhubungan antar-umat beragama dan antarwarga negara di negeri ini.

Kedua, Pendekatan Sosiologis. Kemajemukan etnis dan kultur yang ada di tndonesia memberikankekayaan kearifan lokal untuk mencegah terjadinya konflik yang ada disetiap daerah di negeri ini. Karakteristik masyarakat lndonesia yangcenderung komunal masih dianggap efektif dalam mempergunakankearifan lokal sebagai pranata datam mengurai konflik yang terjadi didaerah tersebut. Bahkan dalam beberapa kasus, sebuah konflik yangsulit diredam dengan menggunakan pendekatan politis ataupun yuridis-formal, segera mereda ketika diurai dengan menggunakan pranatakearifan lokal.

Ketiga, Pendekatan Yuridis. Sebagai sebuah Negara hukum tentu saja bangsa ini harus punyaseperangkat peraturan perundangan yang bisa mengikat semua wargabangsa sehingga terhindar dari adanya konflik. Dalam hubungan antarpemeluk agama, bangsa ini telah mempunyai SKB tentang Tata caraPenyiaran Agama, PBM tentang syarat Pendirian Rumah lbadah, danUU tentang Penodaan Agama. Namun peraturan yang telah ada inidinilai kurang kuat kedudukannya, karena tidak termasuk dalam hierarkihukum di lndonesia. Karenanya, dianggap perlu adanya sebuahundang-undang baru yang materinya mengadopsi dari ketiga peraturanperundangan yang telah ada tersebut.

Sampai saat ini bingkai-bingkai yang ada dipandang masih memadaiuntuk menjaga harmoni dan kemajemukan yang ada. Namun demikian ditengah derasnya arus perubahan, bukan tidak mungkin bingkai-bingkaitersebut di masa mendatang tidak lagi dianggap memadai untukmempertahankan dua hal tersebut. oleh karenanya perlu adanya upaya-upaya yang sistematis dan strategis yang perlu dilakukan oleh berbagaipihak, khususnya pihak-pihak yang mempunyai otoritas dalam hal ini,sehingga harmoni dan kemajemukan masih bisa tetap terjaga di negeri ini.

\section{KESIMPULAN}

Dalam mengoptimalisasikan peran lembaga keagamaan untuk mengelola kemajemukan dengan baik, penyelesaian kerukunan umat beragama di Desa Dermolo Kabupaten Jepara menggunakan pendekatan hati, artinya diajak komunikasi intensif dan duduk bersama dengan semua pihak secara rutin hingga dinyatakan tuntas sambil mewaspadai jangan sampai hasil kesepakatan tersebut diprovokasi oleh oknum yang tidak suka dengan kondisi aman dan damai. Adapun caranya adalah :Pertama, Membangun harmoni kemajemukan potensi 
keberagamaan melalui kesepakatan bersama yang dipatuhi; Kedua, Dalam rangka meminimalisir berulangnya konflik dan disintegrasi, maka Pemkab, FKUB, Polres dan Kemenag segera melakukan gerakan ishlabul ummah dan melakukan penguatan kemajemukan melalui berbagai pendekatan politis, teologis, sosiologis, dan yuridis; Ketiga, Membangun harmoni keberagamaan melalui penyamaan pola pikir (taswiyah al-manhaj) dan koordinasi langkah strategis dalam masalah keagamaan (tansiq al-harakah); Keempat,Penyamaan pola pikir dalam masalah keagamaan (taswiyah al-manhaj).

Pihak yang dianggap berperan dalam upaya menciptakan iklim kondusif di lingkungan bangunan yang diduga gereja Desa Dermolo Kecamatan Kembang Kabupaten Jepara adalah semua pihak baik Pemerintah Kabupaten beserta jajarannya sampai ke bawah, Polres, Kodim, Kemenag, FKUB dan utamanya elemen masyarakat di Desa Dermolo sendiri.

\section{DAFTAR PUSTAKA}

A.Gunawan Setiardja, Dialektika Hukum dan Moral Dalam Pembangunan Masyarakat Indonesia, Yogyakarta: Kanisius, 1990

Abu Abdillah Muhammad bin Ahmad al Qurthubhi, al Jami li Ahkam al Qur'an, Jilid V, Beirut: Daar al Fikr, t.thn.

Abu Ishak as Sairozi, Al Muhadzab, Juz I, Mesir: Mathba ’ah al Babi al Halabi., t.thn.

Adji Samekto, Pembangunan Berkelanjutan Dalam Tatanan Sosial Yang Berubah, Jurnal Hukum Progresif, Volume 1 Nomor 2, Oktober 2005, Program Doktor Ilmu Hukum Universitas Diponegoro Semarang

Adriaan Bedner, Administration Courts in Indonesia: A Socio-legal Study, Belanda: Leiden University, 2000

Al Dardiri, al Syarh al Kabir Hasiyah Dasuki, Jilid III, Mesir: Al Babi al Halabi, t.thn.

Al Dardiri, Al Syarh al Kabir Hasyiyah Dasuki, Jilid III,Mesir: Matba ah al Babi al Halabi, t.thn.

Al Imam Jalaluddin al Mahaly dan Jalaluddin as Suyuthi, Tafsir al Qur an al Karim, Juz I, Beirut: Daar al Fikr, 1998 
Al Syarbini al Khatib, Mughni al Mubtaj Syarh al Minhaj, Juz II, Mesir: Mathba ah al Babi al Halabi., t.thn.

Andi Hamzah, Asas-Asas Hukum Pidana, Jakarta: Rineka Cipta, 1991

Barda Nawawi Arief, Kapita Selekta Hukum Pidana, Bandung: Citra Aditya Bakti, 2003

Esmi Warassih, Basis Sosial Hukum: Pertautan Ilmu Pengetahuan Hukum dan Ilmu Pengetabuan Sosial (dalam Pranata Hukum, Sebuah Telaah Sosiologis), Semarang: PT Suryandaru Utama, 2005

Ibn Abidin, Hasyiyah Rad al Mukhtar ala Dur al Mukhtar, Jilid V, Mesir: Al Babi al Halabi, t.thn.

Paulus Hadisuprapto, Peradilan Restoratif: Model Peradilan Anak Indonesia Masa Datang, Pidato Pengukuhan Guru Besar Fakultas Hukum Universitas Diponegoro, Semarang, 18 Februari 2006

Philippe Nonet Dan Philip Selznick, Law and Society in Transition Toward Responsive Law, diterjemahkan menjadi Hukum Responsif Piliban di Masa Transisi, Jakarta: Huma, 2003

Wahbah al Zuhayli, Fiqh Islam wa Adillatuh, Beirut: Daar al Fikr, 1999 Yusriyadi, Strategi Pembangunan Nasional Bidang Hukum Era Orde Baru (Analisis Teoritik Tentang Kebijakan dan Implikasinya Terbadap Penyelenggaraan Hukum di Indonesia), Jurnal Masalah-Masalah Hukum Fakultas Hukum Universitas Diponegoro, Edisi VIII Januari-Maret 2000 
Menyelesaikan Konfilk ...

Mashudi 